\title{
COMMENTS
}

\section{The Defendant Joinder Problem in Title VII Civil Actions}

Title VII of the Civil Rights Act of $1964^{1}$ established an elaborate scheme to enforce its prohibition of discrimination in employment practices on the basis of race, color, religion, sex, or national origin. An individual aggrieved by an alleged unlawful employment practice must file a charge with the Equal Employment Opportunity Commission, which investigates the charge and attempts to secure voluntary compliance with the Act. If the EEOC administrative process fails to produce a satisfactory settlement, the aggrieved person may initiate a civil action to remedy the violation in federal district court.

The language of Title VII, however, significantly limits the subject matter jurisdiction of the federal district courts by providing that civil actions can only be maintained against alleged discriminators named in a charge filed with the EEOC. ${ }^{2}$ Thus, for example, the Title VII complainant who files a charge with the EEOC without the aid of an attorney ${ }^{3}$ may subsequently discover that his judicial relief in a Title VII civil action is limited because he failed to name all appropriate parties as respondents before the EEOC. ${ }^{4}$

This comment will argue that such a limitation on subject matter jurisdiction is inconsistent with the underlying purpose of Title VII-to provide effective relief against unlawful employment practices. ${ }^{5}$ It begins with an analysis of the Title VII enforcement

1. 42 U.S.C. $\S \S 2000 \mathrm{e}$ to $2000 \mathrm{e}-15$ (1970), as amended, 42 U.S.C. $\$ \S 2000 \mathrm{e}$ to $2000 \mathrm{e}-17$ (Supp. II, 1972) [hereinafter referred to in text as Title VII].

2. See text and notes at notes 23-24 infra.

3. Of course, even an attorney may not be certain at the EEOC stage of the enforcement process whether a given party will subsequently be considered a necessary or indispensable party under Rule 19 of the Federal Rules of Civil Procedure. See FED. R. CIv. P. 19; text and notes at notes $23-33$ infra.

4. See, e.g., Mickel v. South Carolina State Employment Serv., 377 F.2d 239 (4th Cir.), cert. denied, 389 U.S. 877 (1967).

5. The Supreme Court has emphasized that creation of procedural technicalities is "inappropriate in a statutory scheme in which laymen, unassisted by trained lawyers, initiate the process." Love v. Pullman Co., 404 U.S. 522, 527 (1972). See Comment, Title VII of the Civil Rights Act of 1964: Obtaining Jurisdiction Over Respondents Who Were Not Named as Respondents in a Charge to the EEOC, 75 Dick. L. REv. 99, 106-08 (1970). 
procedure and the general obstacles to bringing suit against parties not named as respondents before the EEOC. The comment then critically examines the approaches used by several lower federal courts to circumvent the explicit statutory restriction on their subject matter jurisdiction in Title VII actions. The comment concludes by proposing several amendments to the statute that would permit defendants not named before the EEOC to be joined without significant interference with other interests that the statute was designed to protect.

\section{The Problem of Defendant Joinder in}

\section{Title VII Proceedings in the Federal District Courts}

\section{A. Statutory Framework}

Title VII of the Civil Rights Act of 1964 proscribed certain discriminatory employment practices ${ }^{6}$ and established the Equal Employment Opportunity Commission, ${ }^{7}$ which was to "endeavor to eliminate any such alleged unlawful employment practice by informal methods of conference, conciliation, and persuasion."8 This informal conciliation process is triggered when either a person claiming to be aggrieved by alleged unlawful employment practices or a member of the Commission files a written charge with the Commission. ${ }^{9}$ If the charge is timely-filed within 180 days after the alleged discrimination occurre ${ }^{10}$ - the Commission is required to notify the alleged discriminator of the charge and then to determine whether there is reasonable cause to believe that the charge is valid.11

If the Commission reaches a finding of reasonable cause, it encourages the complainant and the respondents named in the charge to enter the conciliation process in order to obtain a voluntary settlement of all issues without an action in the district court. ${ }^{12}$ The primary emphasis of this administrative process is on vindication of equal employment opportunity rights through informal and voluntary conciliation; the Commission has the power neither to

6. 42 U.S.C. $\S \S 2000 \mathrm{e}-2$ to $2000 \mathrm{e}-3$ (Supp. II, 1972).

7. Id. $\$ 2000 \mathrm{e}-4$.

8. Id. $\S 2000 \mathrm{e}-5(\mathrm{~b})$. This process will be referred to throughout this comment as the conciliation process.

9. Id.

10. Id. $\S 2000 \mathrm{e}-5(\mathrm{e})$. The 180 day period is extended for aggrieved persons who file charges with qualified state or local enforcement agencies. $I d$.

11. Id. $\S 2000 \mathrm{e}-5(\mathrm{~b})$.

12. See King v. Georgia Power Co., 295 F. Supp. 943, 947 (N.D. Ga. 1968). 
compel participation in the conciliation process nor to order compliance with the Act. Participation in the informal proceedings is encouraged by a requirement of confidentiality, in that nothing said or done during the process can be made public or used in subsequent proceedings without the consent of the persons concerned. ${ }^{13}$ The courts have interpreted this administrative enforcement procedure as having a dual purpose: to provide the charged party with advance notice of the charge and to promote voluntary compliance and conciliation. ${ }^{14}$

Nevertheless, Title VII does authorize the Commission to bring a civil action in federal district court if it is unable to achieve compliance through conciliation. ${ }^{15}$ And in the event that the Commission dismisses the charge, or has neither filed a civil action nor successfully conciliated the dispute within 180 days after the filing of written charges, the Act authorizes civil actions by either the persons who filed the charge or, if the charges were filed by a member of the Commission, by any person whom the charge alleges to have been aggrieved by an unlawful employment practice. ${ }^{16}$ If such a civil action is filed, the trial court proceedings constitute a de novo adjudication of all issues of law and fact; the court does not review the Commission proceedings or substitute its judgment for that of the Commission. ${ }^{17}$

This statutory framework is thus designed to protect several competing interests. First, it is intended to assure timely and effective enforcement of Title VII rights; the statute establishes time limits for each step in the enforcement process $^{18}$ and provides for

13. 42 U.S.C. $\$ 2000$ e-5(b) (Supp. II, 1972).

14. Evans v. Sheraton Park Hotel, 503 F.2d 177, 183 (D.C. Cir. 1974); Bowe v. ColgatePalmolive Co., 416 F.2d 711, 719 (7th Gir. 1969).

15. 42 U.S.C. $\S 2000 \mathrm{e}-5(\mathrm{f})(\mathrm{I})$ (Supp. II, 1972). If one of the respondents is a government, government agency, or political subdivision, the Attorney General rather than the EEOC is authorized to sue. $I d$.

16. Id. The term aggrieved person will be used throughout this comment to refer both to persons filing charges before the EEOC and to persons who are covered by a charge filed by a member of the Commission.

17. Thus, even if the Commission concludes that there is not reasonable cause to believe that the charge is valid, the aggrieved person can file a civil action. See McDonnell Douglas Corp. v. Green, 411 U.S. 792, $798-99$ (1972).

18. The Commission must make its reasonable cause determination "as promptly as possible" and generally within 120 days after the filing of a charge. 42 U.S.C. $\$ 2000 \mathrm{e}-5$ (b) (Supp. II, 1972). If the Commission is unable to secure voluntary compliance within 30 days after a charge is filed, it may initiate a civil action in federal district court. Id. $\$ 2000 \mathrm{e}-\overline{5}(\mathrm{f})(1)$. If the Commission dismisses the charge, or fails to secure compliance or initiate a civil action within 180 days after a charge is filed, an aggrieved person can initiate a civil action in federal district court within 90 days after the EEOC notifies the person that he has authority to sue. Id. $\$ 2000 \mathrm{e}-5(f)(3)$. The statute also requires that Title VII civil actions be "im- 
judicial enforcement where necessary. ${ }^{19}$ Second, it provides potential defendants with advance notice ${ }^{20}$ of charges of alleged unlawful practices and with a structured informal process for negotiating with the complainant before a civil action is filed. ${ }^{21}$ Finally, it establishes an active role for the EEOG both in conciliating Title VII disputes-and thus reducing the possibility that Title VII cases will add to the already crowded federal district court dockets-and in initiating and participating in litigation in the federal courts to assure enforcement of Title VII rights. ${ }^{22}$

\section{B. The Problem of Proper Defendants}

Section 706(f)(1) of the $\mathrm{Act}^{23}$ authorizes the Commission and aggrieved persons to file a civil action against the "respondent named in the charge" that had been filed with the Commission. The statute thus requires a complainant to proceed through the EEOC before filing a civil action in federal district court, and has been interpreted to preclude civil actions against parties not named as respondents before the EEOC. ${ }^{24}$

The problem of proceeding against a party not named before the EEOC arises in a variety of Title VII claims. A person aggrieved by an unlawful employment practice might file a charge

mediately" assigned to a trial judge, who is instructed to "assign the case for hearing at the earliest practicable date and to cause the case to be in every way expedited." $I d$. \$§ $2000 \mathrm{e}-5(\mathrm{f})(4)$ to $(5)$.

19. In addition to its provisions authorizing suit by the EEOC and private claimants, see note 18 supra, the statute authorizes the EEOC to request "temporary or preliminary relief" pending disposition of the charge before it. 42 U.S.C. $\$ 2000 \mathrm{e}-5(\mathrm{f})(2)$ (Supp. II, 1972).

20. 42 U.S.C. $\$ 2000$ e-5(b) (Supp. II, 1972).

21. Id. § 2000e-5(f)(1). See Evans v. Sheraton Park Hotel, 503 F.2d 177, 183 (D.C. Cir. 1974).

22. See 42 U.S.C. $\S 2000 \mathrm{e}-5(\mathrm{f})(1)$-(2) (Supp. II, 1972). The Commission is also authorized to intervene in a Title VII civil action initiated by an aggrieved party. Id. \& 2000e-(4)(g)(6).

23. If ... the Commission has been unable to secure from the respondent a conciliation agreement acceptable to the Commission, the Commission may bring a civil action against any respondent ... named in the charge. . . If a charge filed with the Commission ... is dismissed by the Commission, or if ... the Commission has not filed a civil action under this section .... or the Commission has not entered into a conciliation agreement to which the person aggrieved is a party, the Commission ... shall so notify the person aggrieved and within ninety days after the giving of such notice a civil action may be brought against the respondent named in the charge (A) by the person claiming to be aggrieved or (B) if such charge was filed by a member of the Commission, by any person whom the charge alleges was aggrieved by the alleged unlawful employment practice....

42 U.S.C. § 2000e-5(f)(1) (Supp. II, 1972) (emphasis added). Prior to 1972, the EEOC did not have the authority to initiate a civil action in federal district court; this authority was added by the 1972 amendments to the Act. Equal Employment Opportunity Act of 1972, Pub. L. No. 92-261, § 3, 88 Stat. 103, amending 42 U.S.C. § 2000e-5(e) (1970).

24. See authorities cited note 46 infra. 
before the EEOC against an employment service, for example, and decide in the course of the subsequent civil action that it is necessary to join the potential employer in order to obtain complete and effective relief. ${ }^{25}$ The problem might also arise when an employee files a charge against his employer and later discovers that effective relief can only be obtained if his local union and its international union are joined as party defendants. ${ }^{26}$ It may even be a named defendant that raises the issue of joining additional parties. ${ }^{27}$ In each situation, the problem generally results from the plaintiffs having had insufficient information; the layman filing a charge with the EEOC is unlikely to know in advance what parties may be necessary or indispensable for obtaining subsequent effective judicial relief. ${ }^{28}$ Moreover, the EEOC staff may itself be unable to make that determination at the investigation and conciliation stage. $^{29}$

The question of jurisdiction over defendants not charged before the EEOC has serious implications for effective enforcement of Title VII rights. If the district court determines that the potential defendant is necessary for just adjudication of the dispute under Rule $19(\mathrm{a})^{30}$ of the Federal Rules of Civil Procedure but concludes

25. See Mickel v. South Carolina State Employment Serv., 377 F.2d 239 (4th Cir.), cert. denied, 389 U.S. 877 (1967) (employer named in initial civil complaint).

26. See Evans v. Sheraton Park Hotel, 503 F.2d 177 (D.C. Cir. 1974) (motion to join international union under FED. R. Civ. P. 19).

27. See, e.g., Torockio v. Chamberlain Mfg. Co., 51 F.R.D. 517 (W.D. Pa. 1970).

28. A complainant may, of course, exclude a party at the EEOC stage intentionally, because of a fear of retaliation or a belief that attempts at conciliation would be more successful in the party's absence.

29. The question of whether a party is necessary or indispensable for just adjudication under Rule 19 of the Federal Rules of Civil Procedure, for example, is essentially a question of law for the court. On the basis of the limited information before it, the Commission obviously cannot predict whether a court would eventually conclude that an obscure party is needed for just adjudication. See, e.g., Evans v. Sheraton Park Hotel, 503 F.2d 177, 183 (D.C. Cir. 1974).

30. Rule 19(a) provides:

A person who is subject to service of process and whose joinder will not deprive the court of jurisdiction over the subject matter of the action shall be joined as a party in the action if (1) in his absence complete relief cannot be accorded among those already parties, or (2) he claims an interest relating to the subject of the action and is so situated that the disposition of the action in his absence may (i) as a practical matter impair or impede his ability to protect that interest or (ii) leave any of the persons already parties subject to a substantial risk of incurring double, multiple, or otherwise inconsistent obligations by reason of his claimed interest. If he has not been so joined, the court shall order that he be made a party. If he should join as a plaintiff but refuses to do so, he may be made a defendant, or, in a proper case, an involuntary plaintiff. If the joined party objects to venue and his joinder would render the venue of the action improper, he shall be dismissed from the action.

FED. R. Civ. P. 19(a). 
that failure to name the potential defendant before the EEOC is a jurisdictional bar to joinder, the civil action must proceed without the potential defendant. ${ }^{31}$ In that case, if the plaintiff has become unable to charge the potential defendant before the EEOC because the time period for filing a charge has expired, he may be left with an ineffective remedy. Even more importantly, if the district court determines that the potential defendant is an indispensable party under Rule $19(\mathrm{~b})^{32}$ and that there is a jurisdictional bar to joinder, the civil action must be dismissed..$^{33}$

\section{Legislative History}

The legislative history of Title VII's enforcement procedure provides few clues as to Congress's intent concerning the defendant joinder issue. ${ }^{34}$ The original bill that passed in the House of Representatives, ${ }^{35}$ authorized the EEOC, if conciliation failed, to

31. A somewhat analogous problem arises in cases that are in federal court on the basis of diversity jurisdiction. See 28 U.S.C. $\S 1332$ (1970). The established interpretation of section 1332 is that there must be complete diversity of citizenship between plaintiffs and defendants. Strawbridge v. Curtiss, 7 U.S. (3 Cranch) 267 (1806). A necessary nondiverse party may not be joined if doing so would destroy complete diversity, see, e.g., Dunham v. Robertson, 198 F.2d 316 (10th Cir. 1952), and such a party may be dismissed from an action to preserve diversity jurisdiction over the other parties. See, e.g., Jett v. Phillips \& Associates, 439 F.2d 987, 989-90 (10th Cir. 1971). In a Title VII case, on the other hand, failure to charge a party before the EEOC precludes asserting subject matter jurisdiction over that party but does not deprive the court of jurisdiction over the action itself. $C f$. Sabolsky v. Budzanoski, 457 F.2d 1245 (3d Cir.), cert. denied, 409 U.S. 853 (1972) (dismissal of only those defendants over whom subject matter jurisdiction could not be asserted under the LaborManagement Reporting and Disclosure Act).

32. Rule $19(\mathrm{~b})$ provides:

If a person as described in subdivision (a)(1)-(2) hereof cannot be made a party, the court shall determine whether in equity and good conscience the action should proceed among the parties before it, or should be dismissed, the absent person being thus regarded as indispensable. The factors to be considered by the court include: first, to what extent a judgment rendered in the person's absence might be prejudicial to him or those already parties; second, the extent to which, by protective provisions in the judgment, by the shaping of relief, or other measures, the prejudice can be lessened or avoided; third, whether a judgment rendered in the person's absence will be adequate; fourth, whether the plaintiff will have an adequate remedy if the action is dismissed for nonjoinder.

FED. R. Crv. P. 19(b).

33. Id. The diversity analogy applies here also. A civil action based on diversity jurisdiction must be dismissed if there is a nondiverse indispensable party. See, e.g., Travelers Indem. Co. v. Westinghouse Elec. Corp., 429 F.2d 77, 79-80 (5th Cir. 1970).

34. "The stormy legislative history" of Title VII renders the intent of Congress in its administration far from clear." Evans v. Sheraton Park Hotel, 503 F.2d 177, 183 (D.C. Cir. 1974). See generally EQUAL OPPORTUNity EMPLOYMENT CoMmission, Legislative History of Titles VII and XI of the Civil Rights Act of 1964 (1968).

35. H.R. 7152, 88th Cong., lst Sess. (1963) (House version). See 110 Cong. Rec. 2804-05 (1964); H.R. ReP. No. 914, 88th Cong., 1st Sess. (1963). 
bring a civil action to "prevent the respondent" from engaging in unlawful employment practices. ${ }^{36}$ The aggrieved person was authorized to initiate a civil action if the EEOC failed or declined to bring its own action. ${ }^{37}$ Instead of being referred to a Senate committee, the House bill went directly to the floor of the Senate where, faced with a filibuster, supporters of the House bill and the Senate leadership worked out a compromise bill. The compromise bill eliminated the EEOC's authority to institute civil actions when conciliation failed but retained a provision authorizing an aggrieved person to file a civil action against the "respondent named in the charge" before the EEOC. ${ }^{38}$ Cloture was invoked shortly thereafter and the compromise version passed the Senate. The version of the bill that passed in the Senate was sent directly to the House rather than to a joint conference committee, and it was passed without amendment. ${ }^{39}$

The legislative history of Title VII's enforcement procedure thus fails to clarify congressional intent concerning the defendant joinder problem. There is neither a Senate committee report nor a conference committee report, and the House report analyzes a bill containing enforcement language that differs substantially from the version that eventually was enacted. ${ }^{40}$ Finally, the defendant joinder problem was not even considered in the course of the floor debates. ${ }^{41}$

Title VII was amended in 1972 to authorize the EEOC, as well as aggrieved parties, to initiate a civil action in federal court against respondents named in charges before the Commission. ${ }^{42}$ The legislative history of this 1972 amendment also fails to indicate congressional intent concerning the defendant joinder problem. ${ }^{43}$

36. H.R. 7152, 88th Cong., 1st Sess. \$ 707(b) (1963) (House version).

37. The aggrieved person had to obtain the permission of at least one member of the Commission before initiating suit. $I d . \S 707$ (c) (1963).

38. H.R. 7152, 88th Cong., 1st Sess. § 706(e) (1963) (Mansfield-Dirksen substitute, Amendment 656).

39. 110 CoNG. REC. 15897 (1964).

40. See Vaas, Tïlle VII: Legislative History, 7 B.C. IND. \& Com. L. Rev. 431, 452-54 (1966).

41. Oddly enough, Senator Humphrey, the floor manager of the bill in the Senate, was not even aware that the proposed bill required a complainant to resort to the EEOC before initiating a civil action in federal district court. In an exchange with Senator Cannon, he expressed the opinion that a complainant could completely bypass the EEOC. 110 Cong. REC. 14188 (1964). The federal courts, however, have uniformly interpreted Title VII as requiring a complainant to exhaust his remedies before the EEOC. See, e.g., Stebbins v. Nationwide Ins. Co., 382 F.2d 267 (4th Cir. 1967), cert. denied, 390 U.S. 910 (1968).

42. Equal Employment Opportunity Act of 1972, Pub. L. No. 92-261, § 3, 88 Stat. 103, amending 42 U.S.C. $\$ 2000 \mathrm{e}-5$ (e) (1970).

43. See Subcomm. on Labor, Senate Comm. on labor and Public Welfare, 92d Cong., 


\section{Federal Jurisdiction of Title VII Claims Against NonRespondent Defendants}

Section 706(f)(3) of the Act ${ }^{44}$ grants "jurisdiction of actions brought under this subchapter" to the federal district courts, including civil actions filed under section $706(f)(1)^{45}$ against parties charged before the EEOC (respondent defendants). A number of lower federal courts have narrowly construed this grant of jurisdiction and have either dismissed from the district court action or refused to allow joinder of nonrespondent defendants-defendants who had not been named as respondents before the EEOC. ${ }^{46}$ In Mickel v. South Carolina State Employment Service, ${ }^{47}$ for example, the complainant attempted to name both a state employment service and a potential employer in his complaint in federal district court after having named only the state employment service in the charge filed with the EEOC. The Fourth Circuit affirmed the district court's grant of summary judgment for the potential employer on the ground that it had not been charged before the EEOC. ${ }^{48}$

At the outset, it is important to distinguish cases like Mickel-involving joinder of parties who could have been charged before the EEOC-from cases in which the parties sought to be joined are not employers, ${ }^{49}$ employment agencies, ${ }^{50}$ or labor organizations, ${ }^{51}$ which are the only parties subject to Title VII's prohibitions. Joinder in the district court proceeding of necessary and indispensable parties who could not have been joined before the EEOG can be supported on a theory of ancillary jurisdiction. ${ }^{52}$

2D Sess., Legislative History of the Equal Employment Opportunity Act of 1972 (Comm. Print 1972).

44. 42 U.S.C. $\S 2000 \mathrm{e}-5(f)(3)$ (Supp. II, 1972).

45. Id. $\S 2000 \mathrm{e}-5(f)(1)$.

46. Williams v. General Foods, 492 F.2d 399, 404-05 (7th Gir. 1974); LeBeau r. LibbyOwens-Ford, 484 F.2d 798, 799 (7th Cir. 1973); Marlowe r. Fisher-Body, 6 EPD Cases I 8997, at 6236 (6th Cir. 1973); Bowe v. Colgate Palmolive Co., 416 F.2d 711, 719 (7th Cir. 1969); Miller r: International Paper Co., 408 F.2d 283, 291 (5th Cir. 1969); Mickel $x$ South Carolina State Employment Serv., 377 F.2d 239, 242 (4th Cir.), cert. denied, 389 U.S. 877 (1967); Jamison v. Olga Coal Co., 335 F. Supp. 454, 460 (S.D.W. Va. 1971); Butler r: Laborers' Locals 4 \& 269, 308 F. Supp. 528, 531 (N.D. Ill. 1969); Cox v. United States Gypsum Co., 284 F. Supp. 74, 76 (N.D. Ind. 1968); Moody v. Albemarle Paper Co., 271 F. Supp. 27, 29 (E.D.N.C. 1967).

47. 377 F.2d 239 (4th Cir.), cert. denied, 398 U.S. 877 (1967).

48. Id. at 242 .

49. 42 U.S.C. $\$ 2000 \mathrm{e}$ (b) (Supp. II, 1972).

50. Il. $\$ 2000 \mathrm{e}(\mathrm{c})$.

51. Id. $\$ 2000 \mathrm{e}(\mathrm{d})$.

52. For example, in Pegues v. Mississippi State Employment Serv., 57 F.R.D. 102, 105 (N.D. Miss. 1972), the court ordered joinder of the Secretary of Labor under Rule 19(a) 
Joinder of such parties would not contravene the limits on subject matter jurisdiction explicitly mentioned in Title VII. On the other hand, joinder of parties who could have been joined before the EEOC would directly violate the restriction that Congress placed on the subject matter jurisdiction of the federal courts. Thus, although ancillary jurisdiction may justify the joinder of nonrespondent defendants in some cases, it cannot justify joinder of defendants against whom independent Title VII claims would lie.

In cases involving nonrespondent defendants against whom a Title VII charge could have been brought, the refusal to allow their joinder can seriously impair the ability of a district court to remedy the alleged unlawful employment practice. ${ }^{53}$ Indeed, if the district court concludes that a nonrespondent defendant is an indispensable party within the meaning of Rule $19(\mathrm{~b}),{ }^{54}$ the entire action must be dismissed. ${ }^{55}$ Since this latter possibility may involve complete denial of judicial relief if the complainant is precluded by section 706(e)'s 180 day rule ${ }^{56}$ from naming the nonrespondent defendant in a new charge before the EEOC, most federal courts have concluded that nonrespondent defendants are dispensable parties. ${ }^{57}$ Several federal courts have gone even further and, in an attempt to assure complete and effective relief for Title VII plaintiffs with valid claims, have utilized a variety of other theories to maintain that failure to charge a party before the EEOC is not a bar to proceeding against that party in a civil action.

because the relief sought would have violated regulations promulgated by the Secretary and would have subjected the defendant employment service to multiple or inconsistent obligations in the absence of the Secretary. The Secretary of Labor could not have been charged before the EEOC on the facts of the case. See Bremer v. St. Louis S.W.R.R., 310 F. Supp. 1333, 1340 (E.D. Mo. 1969) (joinder of party who had received a contested job). But see Reyes v. Missouri-Kan.-Tex. R.R., 53 F.R.D. 293 (D. Kan. 1971) (joinder of a local union that could have been charged before the EEOC allowed under Rule 19, relying on Bremer). See generally C. WRIGHT, Federal Courts $\$ 9$ (2d ed. 1970).

53. See, e.g., Evans r. Sheraton Park Hotel, 503 F.2d 177, 180-81 (D.C. Cir. 1974).

54. FED. R. Crv. P. 19(b). See note 32 supra.

55. See, e.g., EEOC x. United States Pipe \& Foundry Co., 375 F. Supp. 237, 245 (N.D. Ala. 1974); Waters v. Wisconsin Steel Wks. of Int'l Harvester Co., 301 F. Supp. 663, 667 (N.D. Ill. 1969), rer'd on other grounds, 427 F.2d 476 (7th Cir.), cert. denied, 400 U.S. 911 (1970).

56. "A charge under this section shall be filed within one hundred and eighty days after the alleged unlawful employment practice occurred ... ." 42 U.S.C. $\$ 2000 \mathrm{e}-5$ (e) (Supp. II, 1972).

57. See, e.g., LeBeau v. Libby-Owens-Ford Co., 484 F.2d 798, 801-02 (7th Cir. 1973); Butler v. Laborers' Locals 4 \& 269, 308 F. Supp. 528, 532 (N.D. Ill. 1969). See also 3A J. Moore, Federal Practice 19.07-2[4], at 2262 n.3 (2d ed. 1974). 


\section{A. The Agency Relationship Theory}

Several courts have suggested in dicta, ${ }^{\mathbf{5 8}}$ and at least one court has held, ${ }^{59}$ that a Title VII plaintiff may proceed against a party not charged before the EEOC if an agent of that nonrespondent defendant had been named in the initial EEOC charge. For example, this agency theory could justify joinder of an international union that had not been named in the charge filed with the EEOC if a member local union had actually been charged. Courts discussing this agency theory have emphasized, however, that more than "mere affiliation" is required to establish a relationship sufficient to justify joinder.$^{60}$ Specifically, the relationship between the two parties must be close enough to warrant treating one party as the agent of the other party for the purpose of conciliation. ${ }^{61}$

This approach enables the court to conclude that a nonrespondent defendant, through its relationship with a respondent defendant, has notice of the charges filed with the EEOC. Since the nonrespondent defendant would have had an opportunity to remedy the alleged unlawful employment practice and to engage in discussions with the complainant, his interests would be protected even if joinder were permitted in the district court proceeding. And the interests of the complainant and respondent defendants would certainly not be adversely affected by allowing joinder of the "principal" nonrespondent defendant. The agency relationship theory therefore appears to violate neither the letter nor the spirit of Title VII.

Nevertheless, the agency relationship theory is of limited practical value because it requires so significant a relationship between the nonrespondent defendant and the respondent defendant. When, as in most cases, the relationship is nonexistent or weak -for example, "mere affiliation"-it is unreasonable to treat the

58. Mickel v. South Carolina State Employment Serv., 377 F.2d 239, 241 (4th Cir.) (dictum), cert. denied, 389 U.S. 877 (1967); Sokolowski v. Swift \& Co., 286 F. Supp. 775, 782 (D. Minn. 1968) (dictum); Moody v. Albemarle Paper Co., 271 F. Supp. 27, 29 (E.D.N.C. 1968) (dictum).

59. Taylor v. Armco Steel Corp., 373 F. Supp. 885, 911 (S.D. Tex. 1973).

60. Moody v. Albemarle Paper Co., 271 F. Supp. 27, 29 (E.D.N.C. 1967). See also Mickel v. South Carolina State Employment Serv., 377 F.2d 239, 24 I (4th Cir.), cert. denied, 389 U.S. 877 (1967); Sokolowski v. Swift \& Co., 286 F. Supp. 755, 782 (D. Minn. 1968).

61. In one federal district, the courts have rejected the agency theory but have allowed a nonrespondent to be joined where there was "substantial identity" between that party and a party charged before the EEOC. McDonald v. American Fed'n of Musicians, $308 \mathrm{~F}$. Supp. 664, 669 (N.D. III. 1970) (substantial identity); Butler v. Laborers' Locals 4 \& 269, 308 F. Supp. 528, 531 (N.D. Ill. 1969) (rejecting agency theory). Accord, Chastang v. Flynn \& Emrich Co., 365 F. Supp. 957, 964 (D. Md. 1973). 
nonrespondent defendant as having had effective notice and an opportunity to negotiate over or remedy the alleged unlawful employment practice, and joinder is thus not justified.

\section{B. The Parallel Civil Rights Action Theory ${ }^{62}$}

A number of federal courts ${ }^{63}$ have recently permitted Title VII plaintiffs to proceed against nonrespondent defendants by establishing a civil rights cause of action under section 1981 of title 42 of the United States Code, ${ }^{64}$ which provides that "[a]ll persons within the jurisdiction of the United States shall have the same right ... to make and enforce contracts, . . . as is enjoyed by white citizens ...." Such a cause of action would have been rejected under early judicial constructions of section 1981 that read a state action requirement into the statute. ${ }^{65}$ But the Supreme Court decision in 1968 in Jones v. Alfred H. Mayer Co. ${ }^{66}$ has enabled federal courts to apply section 1981 to private discrimination ${ }^{67}$ in the contractual relationships between an employee and his employer and between an employee and his union. ${ }^{68}$ In Jones, the Court held that section 1982 of title $42,{ }^{69}$ which guarantees all citizens of the United States the same property rights as those enjoyed by white citizens, applied to "all racial discrimination, private as well as public, in the sale or rental of property." The lower federal courts have extended this private discrimination interpretation to section 1981, since both sections 1981 and 1982 are derived from section 1 of the Civil

62. For a discussion of the relationship between 42 U.S.C. 1981 (1970) and Title VII, see Comment, Racial Discrimination in Employment Under the Civil Rights Act of 1866, 36 U. CHI. L. REv. 615 (1969).

63. Payne v. Ford Motor Co., 461 F.2d 1107, 1107-08 (8th Cir. 1972); Caldwell v. National Brewing Co., 443 F.2d 1044, 1046 (5th Cir. 1971); Young v. ITT, 438 F.2d 757, 758-60 (3d Cir. 1971); Waters v. Wisconsin Steel Wks. of Int'l Harvester Co., 427 F.2d 476, 481-85 (7th Cir.), cert. denied, 400 U.S. 911 (1970). Cf. Brady r. Bristol-Meyers, Inc., 459 F.2d 621, 623 (8th Cir. 1972); Brown v. Gaston County Dyeing Mach. Co., 457 F.2d 1377, 1379 (4th Cir. 1972); Boudreaux v. Baton Rouge Marine Contracting Co., 437 F.2d 1011, 1016 (5th Cir. 1971); Sanders v. Dobbs Houses, Inc., 431 F.2d 1097, 1099-1100 (5th Cir. 1970), cert. denied, 401 U.S. 948 (1971).

64. 42 U.S.C. \$ 1981 (1970).

65. See, e.g., Hurd v. Hodges, 334 U.S. 24, 31 (1948); Virginia v. Rives, I00 U.S. 313 , $317-18$ (1879).

66. 392 U.S. 409 (1968).

67. See cases cited note 63 supra.

68. These relationships are undoubtedly contractual. See Macklin $x$. Spector Freight Systems, Inc., 478 F.2d 979, 993 (D.C. Cir. 1973); Waters r. Wisconsin Steel Wks. of Int'l Harvester Co., 427 F.2d 476, 483 (7th Cir. 1970): Dobbins v. Electrical Workers Local 212, 292 F. Supp. 413, 442 (S.D. Ohio 1968).

69. 42 U.S.C. $\$ 1982(1970)$.

70. 392 U.S. at 413 (emphasis in original). 
Rights Act of $1866 .{ }^{71}$ Moreover, it has been held that the passage of Title VII neither limited nor impliedly repealed the applicability of section 1981 to employment contracts. ${ }^{72}$

This civil rights action theory, like the agency relationship theory, can be used to circumvent the procedural tangle of the nonrespondent defendant problem in only limited circumstances. First, section 1981 applies only to discrimination based on race. ${ }^{73}$ Since over one-third of all EEOC charges involve allegations of discrimination based on religion, sex, or national origin, ${ }^{74}$ the civil rights action theory fails to authorize joinder in a significant number of cases-an asymmetry in result that is a function of the interpretation of section 1981 rather than a legislative policy decision in Title VII itself. Second, section 1981 is inapplicable to certain types of unlawful employment practices, ${ }^{75}$ such as discharge of an employee for filing charges with the EEOC. ${ }^{76}$

\section{Stay of Judicial Proceedings}

A third approach to the nonrespondent defendant joinder problem is to grant a stay of the district court proceedings for up to sixty days under section $706(f)(1)$ of the Act, ${ }^{77}$ for the purpose of allowing the plaintiff to return to the EEOC to name the nonrespondent defendant as a respondent. This approach has the ad-

71. Act of Apr. 9, 1866, ch. 31, § 1, 14 Stat. 27.

72. Brady v. Bristol-Meyers, Inc., 459 F.2d 621, 623-24 (8th Cir. 1972); Caldwell v. National Brewing Co., 443 F.2d 1044, 1046 (5th Cir. 1971); Young v. ITT, 438 F.2d 757, 760-63 (3d Cir. 1971); Boudreaux v. Baton Rouge Marine Contracting Co., 437 F.2d 1011, 1016 (5th Cir. 1971); Sanders v. Dobbs Houses, Inc., 431 F.2d 1097, 1100-01 (5th Cir. 1970), cert. denied, 401 U.S. 948 (1971); Waters v. Wisconsin Steel Wks. of Int'l Harvester Co., 427 F.2d 476, 484-89 (7th Cir.), cert. denied, 400 U.S. 911 (1970). It has also been held that exhaustion of Title VII remedies is not a jurisdictional prerequisite to section 1981 actions. Waters v. Wisconsin Steel Wks. of Int'l Harvester Co., 502 F.2d 1309, 1316 (7th Cir. 1974); Long v. Ford Motor Co., 496 F.2d 500, 503 (6th Cir. 1974).

73. See Jones v. Alfred H. Mayer Co., 392 U.S. 409, 413 (1968); Willingham v. Macon Tel. Publishing Co., 482 F.2d 535, 537 n.l (5th Cir. 1973); Held v. Missouri Pac. R.R., 373 F. Supp. 996, 998 (S.D. Tex. 1974); Abshire v. Chicago \& E.I. R.R., 352 F. Supp. 601, 605 (N.D. Ill. 1972).

74. 7 EEOC ANN. REP. 38 (1972).

75. See Tramble v. Converters Ink Co., 343 F. Supp. 1350, 1354 (N.D. Ill. 1972).

76. 42 U.S.C. $\$ 2000 \mathrm{e}-3$ (Supp. II, 1972).

77. Section $706(\mathrm{f})(1)$ provides:

Upon request, the court may, in its discretion, stay further proceedings for not more than sixty days pending termination of State or local proceedings described in subsection (c) or (d) of this section or further efforts of the Commission to obtain voluntary compliance.

42 U.S.C. $\$ 2000 \mathrm{e}-5(f)(1)$ (Supp. II, 1972). 
vantage of circumventing the nonrespondent defendant problem without denying that defendant an actual opportunity to utilize the EEOC conciliation process.

There are, however, three major difficulties with this approach. First, the EEOC's heavy case load may prevent it from reconsidering a charge as it relates to the new party within the 60 day stay of the district court proceedings. The Commission is already unable to provide conciliation in all cases in which it makes reasonable cause findings ${ }^{78}$ and sometimes is unable to make a reasonable cause determination within the 120 day period required by statute. $^{79}$ It is thus likely that remand to the Commission will accomplish only the addition of a new party to the charge, and not the provision of an opportunity for conciliation. Of course, remand to the EEOC does provide an initial nonrespondent defendant with actual advance notice of the charge and an opportunity to negotiate independently with the complainant. ${ }^{80}$

A second and more serious difficulty with this approach is caused by the statutory requirement that a charge must be filed with the EEOC "within one hundred and eighty days after the alleged unlawful employment practice occurred ...." If If more than one hundred and eighty days have elapsed between the date of the alleged violation and the date of the remand to the EEOC, the Commission will not have jurisdiction over a charge naming the new party. ${ }^{82}$ If the alleged violation is a continuing one, of course, the one hundred and eighty day period may never expire-each day of a continuing alleged unlawful practice constitutes a new violation of the statute. ${ }^{83}$ The courts have been unwilling to ex-

78. 7 EEOC ANN. REP. $51-53$ (1972).

79. Id.

80. It should be noted as well that joinder of a nonrespondent defendant in the district court proceeding provides somewhat similar notice and opportunity.

81. 42 U.S.C. \& 2000e-5(e) (Supp. II, 1972).

82. Nor can the charge against the new party be considered an amendment to the original claim that relates back to the time the initial charge was filed. EEOC regulations authorize amendments only when they cure technical defects in the charge or clarify and amplify the initial allegations, and an amendment may relate back only if it is directly related to or grows out of the subject matter of the original charge. 29 C.F.R. $\$ 1601.11$ (b) (1974); cf. FED. R. Crv. P. 15(c) (allowing relation back of amendments to pleadings charging parties only in limited cases of mistaken identity).

83. Norman v. Missouri Pac. R.R., 414 F.2d 73, 84-85 (8th Cir. 1969) (discriminatory job classification); Mixson v. Southern Bell Tel. \& Tel. Co., 334 F. Supp. 525, 527 (N.D. Ga. 1971) (denial of pension benefits); Sciaraffa v. Oxford Paper Co., 310 F. Supp. 891, 895-96 (D. Me. 1970) (refusal to process grievance). 
pand this continuing violation concept, however, simply to circumvent the nonrespondent defendant problem. ${ }^{84}$

The third difficulty with a stay of judicial proceedings to solve the nonrespondent defendant problem is that it is discretionary. If the trial judge refuses to grant a stay, the plaintiff will be unable to join the nonrespondent defendant unless he can show on appeal that the refusal was an abuse of discretion..$^{85}$

\section{Exhaustion of Administrative Remedies Theory}

At least two federal district courts ${ }^{86}$ have completely excused complainants from the statutory requirement that they file charges with the EEOC before initiating civil actions in federal district court, on the ground that the particular facts of the cases rendered resort to the EEOC futile. ${ }^{87}$ In Washington v. Baugh Construction Co. ${ }^{88}$ the court considered alleged discriminatory practices that had existed for some time in the construction trades in the state of Washington and that had previously been considered by the EEOC under formal charges in a different case. ${ }^{89}$ The court reasoned that although resort to the EEOC for conciliation is generally a prerequisite to a civil action under Title VII, the procedures "would appear frivolous when all previous attempts to achieve such compliance, including informal but serious attempts by the [EEOC], have failed to resolve any of the major issues." 90 Consequently, the court concluded that it had jurisdiction over the Title VII claim even though the complainants had bypassed the EEOC procedure completely. ${ }^{91}$

84. Phillips v. Columbia Gas, Inc., 347 F. Supp. 533, 537-38 (S.D.W. Va. 1972), aff'd, 474 F.2d 1342 (4th Cir. 1973) (termination of employment); Younger v. Glamorgan Pipe \& Foundry Co., 310 F. Supp. 195, 197 (W.D. Va. 1969) (transfer); Cox v. United States Gypsum Co., 284 F. Supp. 74, 79 (N.D. Ind. 1968) (layoff).

85. Cf. Merritt-Chapman \& Scott Co. v. Kent, 309 F.2d 891 (6th Cir. 1962), cert. denied, 372 U.S. 982 (1963); Duisberg v. Markham, 149 F.2d 812 (3d Cir.), cert. denied, 326 U.S. 759 (1945); Girard Trust Co. v. Amsterdam, 128 F.2d 376, 377 (5th Cir. 1942).

86. DeFigueiredo v. Trans World Airlines, Inc., 322 F. Supp. 1384 (S.D.N.Y. 1971); Washington v. Baugh Constr. Co., 313 F. Supp. 598 (W.D. Wash. 1969).

87. For a general discussion of the exceptions to the exhaustion doctrine, see Comment, Exhaustion of State Administrative Remedies in Section 1983 Cases, 41 U. CHI. L. REv. 537, 538-40 (1974).

88. 313 F. Supp. 598 (W.D. Wash. 1969).

89. "[T] he Equal Employment Opportunities [sic] Commission has had a full opportunity to deal with identical issues, involving many of the parties appearing in this action, under formal charges brought before that administrative agency by the plaintiffs in the case of Central Contractors Association, et al. v. Local Union Number 46 . . . . Id. at 605 .

90. Id.

91. Id. 
DeFigueiredo v. Trans World Airlines, Inc. ${ }^{92}$ presents a similar view of the futility of requiring resort to the EEOC. In that case, a male flight cabin attendant bypassed the EEOC and initiated a Title VII action in federal district court, alleging employment discrimination in favor of female attendants. Approximately two years before initiation of that civil action, a female flight attendant had filed charges with the EEOC alleging that TWA discriminated in favor of male attendants; $;^{93}$ the claim was investigated by the EEOC and a reasonable cause finding was made, but conciliation failed. The court in DeFigueiredo concluded that requiring the male attendant to resort to the EEOC would require him to "participate in a charade," especially where there was no suggestion that new information would lead the EEOC to reach a different determination. ${ }^{94}$

The opinions in Baugh Construction and DeFigueiredo indicate that the EEOC charge requirement is sometimes analyzed as a question of exhaustion of administrative remedies rather than a question of subject matter jurisdiction. ${ }^{95}$ But it is difficult to see how the district court proceeding falls within section $706(f)(3){ }^{96}{ }^{96}$ grant of jurisdiction over civil actions against "respondent[s] named in the charge"97 when no charge has been filed with the EEOC. In addition, the Baugh-DeFigueiredo approach has a serious impact on the interests that Title VII was designed to protect. ${ }^{98}$ Nonrespondent defendants are denied advance notice of Title VII charges and an opportunity to participate in structured informal conciliation. The EEOC is denied opportunities both to attempt conciliation among all relevant parties and to exercise its option to file a civil suit in its own name. ${ }^{99}$

92. 322 F. Supp. 1384 (S.D.N.Y. 1971).

93. Id. at $1386-87$ \& n.6.

94. Id. at 1387-88.

95. "[T] $]$ he appropriate administrative procedure with respect to the claim was exhausted . . . DeFigueiredo v. Trans World Airlines, Inc., 322 F. Supp. 1384, 1386 n.7 (S.D.N.Y. 1971).

96. 42 U.S.C. $\$ 2000 \mathrm{e}-5(\mathrm{f})(3)$ (Supp. II, 1972).

97. Id. $\S 2000 \mathrm{e}-5(\mathrm{f})(1)$.

98. Of course, if the court concludes that the plaintiff had adequate administrative remedies, dismissal of the district court action could destroy the plaintiff's Title VII claim in cases in which the statutory 180 day period for filing charges with the EEOC had expired.

99. Both DeFigueiredo and Baugh were decided before enactment of the 1972 amendment giving the EEOC the power to sue in its own name.

This effect on the EEOC's ability to file suit itself might not be serious, since the EEOC is authorized to intervene in Title VII civil actions filed by aggrieved persons. 42 U.S.C. $\$ \$$ $2000 \mathrm{e}-4(\mathrm{~g})(6), 2000 \mathrm{e}-5(\mathrm{f})(1)$ (Supp. II, 1972). Moreover, even if the complainant had been required to resort to the EEOC before proceeding in district court, there is no guarantee 


\section{E. Defendant Motion for Joinder}

The nonrespondent defendant problem can also arise in the context of a motion by a respondent defendant to join a nonrespondent defendant. In Torockio $v$. Chamberlain Manufacturing Co. ${ }^{100}$ for example, the plaintiffs filed a Title VII action against their employer and their local union, both of which had previously been named as respondents before the EEOC. The employer moved to join the international union, which had been a signatory to the labor contract at issue, either as a defendant under Rule $19^{101}$ or as a third party defendant under Rule $14 .{ }^{102}$ The court ordered joinder under Rule $21^{103}$ on the ground that application of the general rule against joinder of nonrespondent defendants would deprive the defendant employer, who had not had an opportunity to join the international before the EEOC, of its "valuable rights under the Federal Rules of Civil Procedure to have a resolution of all facets of the dispute in one proceeding . ..."104

If the respondent defendant attempts to join the nonrespondent defendant under Rule 14 as a third party defendant "who is or may be liable to him for all or part of the plaintiff's claim against him," jurisdiction over the nonrespondent defendant can be established on a theory of ancillary jurisdiction; it is well settled that an independent ground of jurisdiction is not required for joining a third party defendant. ${ }^{105}$ But if the respondent defendant attempts

that the EEOC, given its heavy case load, would have been able to process the case and thus be authorized to file its own action. See id. $\S 2000 \mathrm{e}-5(f)(1)$; text and notes at notes 78-79 supra.

100. 51 F.R.D. 517 (W.D. Pa. 1970).

101. FED. R. CIv. P. 19. See notes 30 \& 32 supra.

102. Rule 14(a) provides:

At any time after commencement of the action a defending party, as a third party plaintiff, may cause a ... complaint to be served upon a person not a party to the action who is or may be liable to him for all or part of the plaintiff's claim against him.

FED. R. CIV. P. 14(a).

103. "Parties may be dropped or added by order of the court on motion of any party or of its own initiative at any stage of the action and on such terms as are just." FED. R. Civ. P. 21. The Torockio opinion contains a confusing discussion of the joinder issue. The court apparently ordered joinder under Rule 21 as an alternative to Rules 14 and 19. See 51 F.R.D. at 519. Rule 21, howerer, merely indicates that the appropriate remedy for failure to join parties who should have been joined under Rules 14 or 19 is joinder rather than dismissal; it is not an alternative rule for determining whether joinder is proper. See C. WRIGHT, supra note $52, \S 71$, at 306 .

104. 51 F.R.D. at 519.

105. " $[T]$ he court having jurisdiction over the aggregate of facts that constitutes the plaintiff's claim needs no additional ground of jurisdiction to determine a third party claim that rests on the same core of facts. On this theory it is abundantly settled that there is ancillary jurisdiction over a third-party clain ... . C. WRIGHT, supra note 52, $\$ 76$, at 336 (footnotes omitted). 
to join the nonrespondent defendant under Rule 19 rather than as a third party defendant, an independent ground of jurisdiction will be required, thus precluding use of the ancillary jurisdiction theory to allow joinder. ${ }^{106}$

The effect on the interests of the nonrespondent defendant who is joined upon motion by another defendant is identical with the impact noted under several other jurisdictional theories-the nonrespondent defendant is denied advance notice of the charge and an opportunity to attempt structured informal conciliation. The respondent defendant who requested joinder obviously benefits when his motion is granted and the nonrespondent defendant is joined. The impact of joinder on the interests of the Title VII plaintiff, however, is uncertain; joinder is presumably advantageous to the plaintiff when he has moved to join the nonrespondent defendant, but that presumption is inapplicable when joinder is granted on the motion of a respondent defendant.

\section{F. Joinder of Obscure Parties After Resort to the EEOC}

In Evans v. Sheraton Park Hotel, ${ }^{107}$ the Court of Appeals for the District of Columbia Circuit offered an interpretation of the charged respondent requirement that would permit joinder of nonrespondent defendants in a broad range of cases. The plaintiff in Evans had filed a charge with the EEOC against her employer, her local union, and a union joint executive board, alleging sex discrimination through maintenance of sexually segregated local unions. The district court granted without prejudice the employer's motion to dismiss for failure to join the international union as an indispensable party. ${ }^{108}$ Subsequently, after the district court vacated that order and permitted the plaintiff to file an amended complaint naming the international union as a defendant, the international moved for summary judgment on the ground that it had not been named as a respondent before the EEOC. ${ }^{109}$ The district court denied the motion, and the court of appeals affirmed. ${ }^{110}$

After concluding that the international union was a necessary party under Rule 19(a), the court of appeals analyzed the statutory

106. See text following note $\mathbf{5 2}$ supra.

107. 503 F.2d 177 (D.C. Cir. 1974).

108. See id. at 180.

109. See id. There was evidence in the record before the court of appeals that the international union, although not formally charged before the EEOC, had actual notice of the charge and subsequent EEOC investigation. See id. at 183 n.4.

110. Id. at $180,184$. 
framework and legislative history of Title VII to determine whether failure to name the international before the EEOC was a jurisdictional bar to joinder under Rule $19 .{ }^{111}$ The court concluded that although a Title VII complainant cannot be permitted to bypass the EEOC completely, congressional emphasis on conciliation was not intended to leave the district court powerless to order joinder of nonrespondent defendants under Rule 19 when a charge had been processed before the EEOC against at least one respondent defendant. ${ }^{112}$ This interpretation of the statutebalancing the value of conciliation against the possibility that a narrow view of Rule 19 joinder would obstruct complete and effective relief-is a convincing solution to the nonrespondent joinder problem, but it fails to indicate the jurisdictional grounds for joinder. The court never explicitly addressed the issue of the absence of the subject matter jurisdiction over the claim against the nonrespondent international union, a jurisdictional defect that bars use of Rule 19(a) to accomplish joinder. ${ }^{113}$

In the course of affirming the district court's denial of summary judgment, the court of appeals discussed several procedural aspects of the Evans action that could partially limit use of this balancing approach. First, the court noted that the complainant waitress in Evans could not be expected to be aware of intricate procedural problems when filing an initial charge with the EEOC, ${ }^{114}$ thus leaving open the possibility that a different result would be proper if there was evidence that the complainant intentionally bypassed an opportunity to name a nonrespondent defendant before the EEOC. This observation might also indicate that the Evans rule should not apply in cases in which a member of the EEOC - who should be more aware of procedural complexities-is the initial charging party. It can be argued that such cases should be resolved in favor of applicability of the Evans approach, since the EEOC had investigated the charge in Evans and therefore had an actual opportunity to charge additional parties in that case. But it is important to note that only a member of the Commission, and not an EEOG investigator, may file a charge.

111. Id. at 183 .

112. Id. The Evans court discussed four district court opinions that it considered persuasive in allowing joinder: Bremer \%. St. Louis Southwestern R.R. and Reyes \%. Missouri-KansasTexas R.R., cited at note 52 supra; Torockio v. Chamberlain Manufacturing Co., discussed in text and notes at notes 100-06 supra; and Pegues v. Mississippi State Employment Serv., 57 F.R.D. 102 (N.D. Miss. 1972), discussed at note 52 supra. See 503 F.2d at 182-83.

113. See text and note at note $\mathbf{5} 2$ supra.

114. 503 F.2d at 183. 
Second, the court noted that it was the defendant employer who directed the district court's attention to the absence of a necessary party. ${ }^{115}$ Although this might be another ground for limiting the court's approach, it would be inconsistent with the thrust of its opinion to argue that nonrespondent joinder is permitted when a respondent defendant raises the issue of absence of a necessary party but not when the plaintiff raises the issue.

Like several of the other joinder theories discussed in this comment, the Evans approach fails to provide the nonrespondent defendant with advance notice of the charges and an opportunity to utilize the EEOG conciliation process.

\section{Proposed Statutory Amendment}

These attempts by the federal courts to circumvent Title VII's narrow grant of subject matter jurisdiction over civil actions against originally named respondents fail to resolve satisfactorily the problem of the nonrespondent defendant. Several approaches, such as the agency theory and the parallel civil rights theory, have only limited applicability. Approaches like that used in Evans are unsatisfactory because they rely on a particular balancing of the statutory policies that may be rejected by other federal courts. And finally, a number of these approaches interfere with the interests in notice to respondents and opportunity to conciliate that the statute was designed to protect. These attempts, though not completely ineffective, point to the need for a statutory amendment to relieve the untrained layman and the EEOC of the burden of having to confront the complexities of subject matter jurisdiction and the Federal Rules of Civil Procedure at the initial stage of the administrative process.

Although there are limitations on its present operation, an amendment of the statutory provision authorizing the district court to stay its proceedings pending further EEOC action could provide a workable solution to the nonrespondent defendant joinder problem. Two major difficulties with this provision under current law are that it is discretionary on the part of the trial judge ${ }^{116}$ and that expiration of the time period for filing charges with the EEOC may preclude charging additional parties before the EEOC during the stay period. ${ }^{117}$ But these two difficulties are easily solved. First, the statute can be amended to provide that the court must grant a sixty 
day stay whenever it concludes that a nonrespondent defendant is a necessary or indispensable party under Rule 19 of the Federal Rules of Civil Procedure and that ancillary jurisdiction cannot be asserted over that party. ${ }^{118}$ Second, the statute can be amended to provide that the time limit for filing a charge with the EEOC is extended whenever a complainant who had already filed a charge obtains a stay of the district court proceedings to charge a necessary or indispensable party. There should, of course, be a statutory limit on the length of the extension-to perhaps six months after the complainant or the EEOC has filed a civil action in federal district court.

One other problem with the current statutory provision authorizing a stay of district court proceedings is that the Commission may be unable to process the case within sixty days because of its heavy case load. ${ }^{119}$ The statute should thus also be amended to allow the district court to exercise its discretion to extend the stay for one additional sixty day period if it concludes that the increased possibility that the Commission may process and conciliate the dispute is worth the added delay.

Together, these suggested changes solve the nonrespondent defendant problem without undue interference with the interests that Title VII was designed to protect. ${ }^{120}$ The EEOC and aggrieved persons are relieved of the burden of dealing with subject matter jurisdiction issues and technical rules of joinder at the administrative stage of the enforcement process. ${ }^{121}$ Respondent defendants receive a second opportunity to negotiate a settlement during the

118. In other words, the district court would not have to grant a stay to enable a plaintiff to file charges against parties that technically cannot be made respondents before the EEOC. See text and notes at notes 49-52 supra.

119. See text and notes at notes 78-80 supra.

120. These suggested changes do not completely solve the problem of a defendant's motion for joinder. See text and notes at notes 100-06 supra. A respondent defendant can successfully join a nonrespondent defendant as a third party defendant under Rule 14 using the doctrine of ancillary jurisdiction. See text and note at note 105 supra. And if the respondent defendant moves to join a nonrespondent defendant under Rule 19 and the court considers the nonrespondent defendant an indispensable party, the Title VII plaintiff will have a strong incentive to request a stay to charge that nonrespondent before the EEOC. The proposed amendments thus fail to resolve the nonrespondent defendant problem only in cases in which (1) the defendant cannot successfully implead the nonrespondent defendant as a third party defendant under Rule 14; (2) the court considers the nonrespondent defendant a necessary rather than an indispensable party; and (3) the plaintiff refuses to charge the nonrespondent before the EEOC.

121. Of course, if there is evidence that the Title VII plaintiff intentionally failed to charge a respondent before the EEOC, a subsequent attempt by the plaintiff to join that nonrespondent in the district court should be denied unless there are exceptional circumstances. 
stay, within or without the EEOC conciliation process. Nonrespondent defendants receive notice of charges and an opportunity to conciliate before being named as defendants in a Title VII civil action. ${ }^{122}$ And finally, the EEOC has the opportunity to conciliate the dispute with all appropriate parties before it.

Thus, this rough spot in the Title VII enforcement framework can easily be remedied by three minor amendments to Title VII. This legislative solution would relieve the courts of the need to rely on limited and unsatisfactory approaches to circumvent the general rule against joining nonrespondent defendants.

\section{Conclusion}

The present statutory provision limiting federal court jurisdiction in Title VII actions to civil suits against parties charged before the EEOC is inconsistent with full and effective enforcement of Title VII rights, and the attempts by the lower federal courts to circumvent the jurisdictional limit are generally unsatisfactory. With minor modifications in the existing statutory framework, however, the procedural technicality that has at times frustrated laymen who are unassisted by trained lawyers ${ }^{123}$ in their pursuit of equal opportunity in employment can be eliminated.

Michael J. Sweeney

122. The only interest protected by Title VII that the proposed amendments would not preserve is the interest of the potential respondent in being immune from Title VII charges after 180 days following his commission of a discrete violation. Although it can be minimized by limiting the length of the extension, his period of potential liability will be of longer duration.

123. See Love v. Pullman Co., 404 U.S. 522, 527 (1972). 